\author{
Article - special issue \\ Doi 10.5943/mycosphere/7/9/19 \\ Copyright $($ Guizhou Academy of Agricultural Sciences
}

\title{
Muyocopron garethjonesii sp. nov. (Muyocopronales, Dothideomycetes) on Pandanus sp.
}

\section{Tibpromma $\mathrm{S}^{1,2,3,4}$, McKenzie EHC ${ }^{6}$, Karunarathna SC ${ }^{4,5}$, Mortimer PE ${ }^{4,5}$, Xu $\mathrm{J}^{4,5}$ and Hyde $\mathrm{KD}^{1,2,3,4,5}, \mathrm{Hu} \mathrm{DM}^{1^{*}}$}

${ }^{1}$ College of Bioscience and Bioengineering, Jiangxi Agricultural University, Nanchang, 330045, China

${ }^{2}$ Center of Excellence in Fungal Research, Mae Fah Luang University, Chiang Rai, 57100, Thailand

${ }^{3}$ Mushroom Research Foundation, 128 M.3 Ban Pa Deng T. Pa Pae, A. Mae Taeng, Chiang Mai 50150, Thailand

${ }^{4}$ Key Laboratory for Plant Diversity and Biogeography of East Asia, Kunming Institute of Botany, Chinese Academy of Science, Kunming 650201, Yunnan, People's Republic of China

${ }^{5}$ World Agroforestry Centre, East and Central Asia, Kunming 650201, Yunnan, P. R. China

${ }^{6}$ Manaaki Whenua Landcare Research, Private Bag 92170, Auckland, New Zealand

Tibpromma S, McKenzie EHC, Karunarathna SC, Xu J Hyde KD and Hu DM 2016 Muyocopron garethjonesii sp. nov. (Muyocopronales, Dothideomycetes) on Pandanus sp. Mycosphere 7 (9), 1480-1489, Doi 10.5943/mycosphere/7/9/19

\begin{abstract}
During a survey of microfungi on leaves of Pandanus species in the Nabanhe Valley at Xishuangbanna, Yunnan Province, China in August 2016, we collected and isolated a new saprobic taxon belonging in Muyocopron (Muyocopronaceae). Both morphological characters and phylogenetic analyses of LSU and SSU sequence data provide strong evidence to place the new taxon in Muyocopron where it is described as $M$. garethjonesii. A description, photoplates of the macro- and micro-characteristics, and a phylogenetic tree to resolve the placement of $M$. garethjonesii are provided.
\end{abstract}

Keywords - Carbonaceous - Pandanaceae - Phylogenetics - Taxonomy

\section{Introduction}

We are interested in microfungi associated with Pandanaceae (Whitton et al. 2012, Tibpromma et al. 2016a, b, c) as the number of fungi known from this host is rather small (Whitton et al. 2012). According to Taylor \& Hyde (2003), Muyocopron can also be found on species of Pandanaceae.

The family Muyocopronaceae was introduced by Luttrell (1951), with Muyocopron Speg. assigned as the type genus (Spegazzini 1881). Eriksson (1981) placed this family in the order Hemisphaeriales as it was considered to have a pleospora-type centrum as in the majority of

Submitted 11 November 2016, Accepted 18 December 2016, Published online 29 December 2016 
Microthyriaceae, Hemisphaeriaceae and Polystomellaceae taxa. Hyde et al. (2013) accepted Muyocopronaceae as a distinct family with the single genus Muyocopron and placed it in class Dothideomycetes.

Muyocopron corrientinum Speg. is the type species of the genus Muyocopron, and characteristic features include distinctive black, dull, rounded regions on the surface of host plants; dimidiate-scutate, subcarbonaceous, ostiolate ascomata, forming superficially on the substrate without mycelium; and bitunicate, 8-spored asci, containing ellipsoidal, hyaline ascospores (Spegazzini 1881, Mapook et al. 2016). Index Fungorum (2016) lists 57 epithets under Muyocopron, with ten species having been transferred to other genera/families (Micropeltidaceae, Microthyriaceae, Nitschkiaceae, Phaeopolystomella and Phyllachoraceae). Muyocopron has been placed in various families by different mycologists (Arx \& Müller 1975, Saccardo 1883, Eriksson \& Hawksworth 1993, Phipps \& Rember 2004, Lumbsch \& Huhndorf 2007, 2010). However, molecular phylogenetic studies indicated that Muyocopron species group with Pleurotrema species in the family Pleurotremataceae (Pang et al. 2013, Maharachchimbura et al. 2016). Mapook et al. (2016) used fresh collections and combined sequence datasets to show Muyocopron to be a distinct lineage with Pleurotremataceae and Acrospermales in Dothideomycetes.

In this paper, we introduce a new species Muyocopron garethjonesii in the family Muyocopronaceae. We provide an analysis of combined LSU and SSU sequence data to infer the phylogenetic placement of the new taxon. A comparison of the new taxon with Muyocopron species, a comprehensive description, a photoplates of the host, and micrographs of the new taxon are provided.

\section{Materials \& methods}

Sample collection and specimen examination

Fresh specimens of Pandanus spp. (Pandanaceae) in the form of dead and fallen leaves were collected from Nabanhe Valley, Xishuangbanna, Yunnan Province, China. The leaves were brought to the laboratory in Zip-lock bags and examined using a JNOEC JSZ4 (ser. No. 030233) stereo microscope. Fruiting bodies were rehydrated in water before sectioning. Sections were cut using a razor blade and microscopic features observed using a Nikon ECLIPSE Ni compound microscope. Photographs were taken with a Canon 600D digital camera mounted on the microscope. All photomicrographs of microscopic fungal structures were measured using Tarosoft $^{\circledR}$ Image Framework program v.0.9.0.7.

\section{Description of cultures}

Malt extract agar (MEA; $30 \mathrm{~g} / \mathrm{L}$ of malt extract, $15 \mathrm{~g} / \mathrm{L}$ of agar, $20 \mathrm{~g} / \mathrm{L}$ of dextrose, $\mathrm{pH}$ $5.6 \pm 0.2$ ) was used as the medium for culturing the isolated fungi. Single spore isolates were obtained following the method of Chomnunti et al. (2014) using MEA and incubated overnight at room temperature $\left(20-25^{\circ} \mathrm{C}\right)$. Germinating ascospores were aseptically transferred to new MEA media plates after 24 hours. Sexual cultures were subcultured and transferred to water agar (WA) media containing sterile toothpicks and pine needles (Phookamsak et al. 2015) and incubated at room temperature for three months to induce the asexual morph. The cultures were incubated at room temperature $\left(20-25^{\circ} \mathrm{C}\right)$ for 4-6 weeks and colonies were then observed. Herbarium specimens were dried using silica gel and deposited in Mae Fah Luang University (MFLU) Herbarium, Chiang Rai, Thailand and Kunming Institute of Botany Academia Sinica 
(HKAS). Ex-type living cultures were deposited in the Mae Fah Luang University Culture Collection (MFLUCC), while duplicate cultures were deposited in Kunming Institute of Botany Culture (KMUCC). Facesoffungi numbers (FoF) and Index Fungorum (IF) numbers were registered as described in Jayasiri et al. (2015) and Index Fungorum (2016).

DNA extraction, PCR amplification and DNA sequencing

Isolates were grown on MEA at room temperature for two weeks, and the fungal mycelia were scraped off and transferred to $1.5 \mathrm{ml}$ Eppendorf tubes. The fungal genomic DNA extraction followed the protocol of Biospin Fungal Genomic DNA extraction Kit-BSC14S1 (BioFlux, P.R. China). Polymerase chain reactions (PCR) were used to amplify partial gene regions LSU (Vilgalys \& Hester 1990) and SSU (White et al. 1990) using primers and conditions as outlined in Tibpromma et al. (2016b). The total volume of PCR mixtures for amplifications were $25 \mu \mathrm{L}$ containing $8.5 \mu \mathrm{L} \mathrm{ddH}_{2} \mathrm{O}, 12.5 \mu \mathrm{L} 2 \times$ Easy Taq PCR Super Mix (mixture of Easy Taq TM DNA Polymerase, dNTPs, and optimized buffer (Beijing Trans Gen Biotech Co., Chaoyang District, Beijing, PR China), $2 \mu \mathrm{L}$ of DNA template, $1 \mu \mathrm{L}$ of each forward and reverse primers (10 pM). The quality of PCR products were checked on $1 \%$ agarose gel electrophoresis stained with $4 \mathrm{~S}$ green nucleic acid (Life Science Products \& Services, Cat. No: A616694). Purification and sequencing of PCR products were carried out by Sangon Biotech Co., Shanghai, China.

\section{Phylogenetic analyses}

LSU and SSU sequence data generated in this study were subjected to BLAST searches in the nucleotide database of GenBank (www http://blast.ncbi.nlm.nih.gov/) to establish the most similar taxa. Sequence data were retrieved from GenBank based on most recent publications (Mapook et al. 2016). Lichenothelia convexa Henssen 1987 (L1607) was used as the outgroup taxon (Table 1). All sequence alignments were done with MAFFT v.6.864b (Katoh \& Standley 2016) and alignments were manually improved if necessary. The sequence datasets were combined using BioEdit v.7.2.5 (Hall 2004). The phylogenetic analyses were performed by using Randomized Accelerated Maximum Likelihood (RAxML) and Bayesian posterior probabilities (BYPP). A maximum likelihood analysis including 1,000 bootstrap replicates was done using RAxML v. 8.2.4 (Stamatakis 2014), which is a part of RAxML-HPC BlackBox tool (Miller et al. 2010). To perform Bayesian analysis, the model of evolution was estimated by using MrModeltest 2.2 (Nylander 2004) with the nucleotide substitution models selected for combined datasets as GTR $+\mathrm{I}+\mathrm{G}$. Posterior probabilities (PP) (Rannala \& Yang 1996) were established by Markov Chain Monte Carlo sampling (MCMC) in MrBayes v $3.0 b 4$ (Liu et al. 2012). Six simultaneous Markov chains were run for 1,000,000 generations and trees were sampled every $100^{\text {th }}$ generations (Cai et al. 2006). The first 2,000 trees, representing the burn-in phase of the analyses, were discarded and the remaining 8,000 (post-burning) trees used for calculating posterior probabilities (PP) in the majority rule consensus tree (critical value for the topological convergence diagnostic set to 0.01) (Zhaxybayeva \& Gogarten 2002, Ariyawansa et al. 2015). The phylogenetic trees were figured in FigTree v. 1.4 (Rambaut \& Drummond 2008) and edited using Microsoft Office PowerPoint 2007 and Adobe illustrator CS3 (Adobe Systems Inc., USA). Sequences derived in this study were deposited in GenBank, and the alignments in TreeBASE (www.treebase.org) submission ID: 20286. 


\section{Results and discussion}

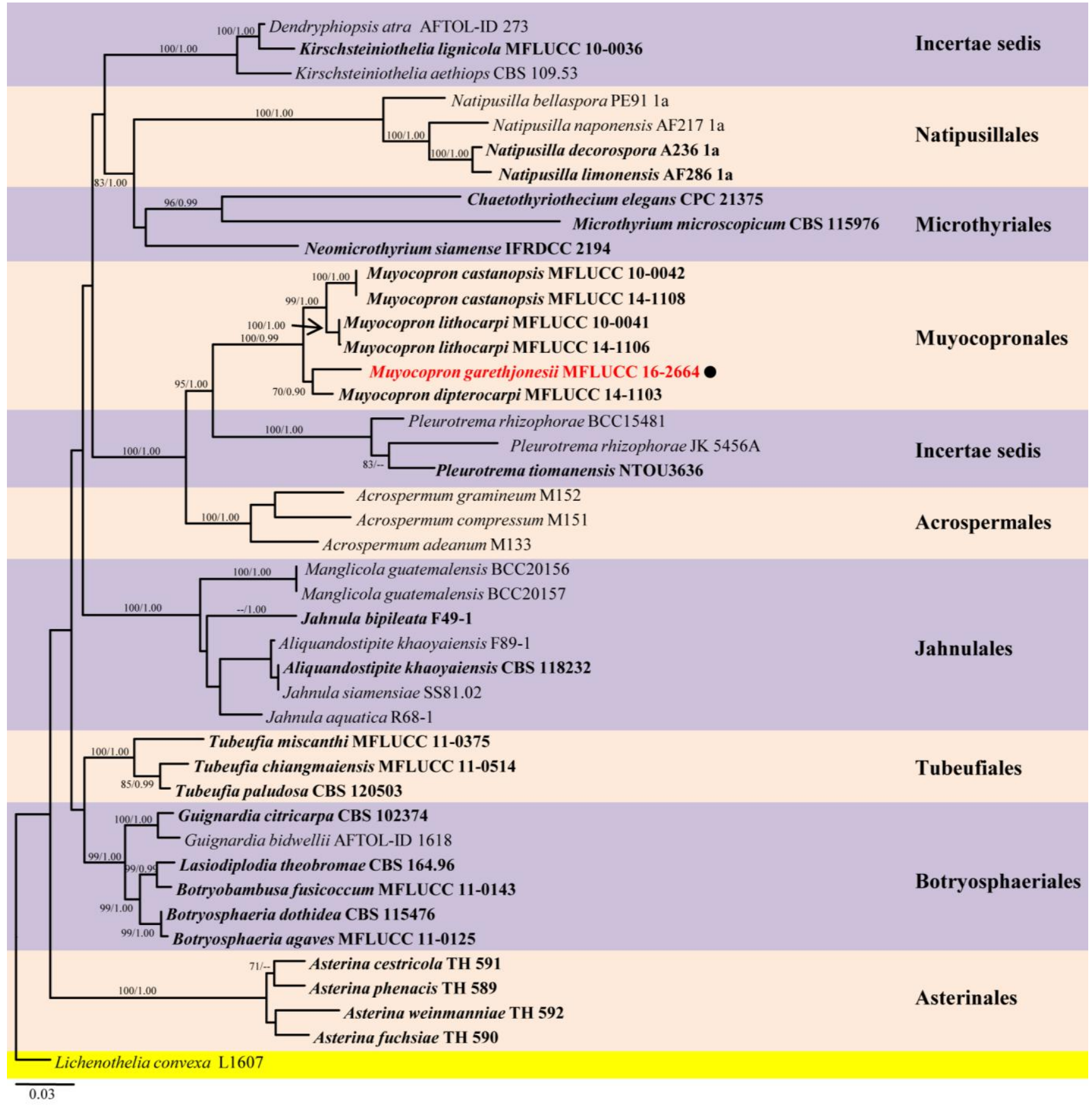

Fig. 1. Phylogram generated from RAxML based on combined LSU and SSU sequence data. Bootstrap support values for maximum likelihood (ML, left) greater than $70 \%$ and Bayesian posterior probabilities (PP, right) equal to or greater than 0.90 are indicated at the nodes. The extype and reference sequences are in bold. The newly generated sequences are in red with black dots. 
Table 1. Taxa used in the phylogenetic analyses and their GenBank accession numbers. The new taxon is indicated with an asterisk.

\begin{tabular}{|c|c|c|c|}
\hline \multirow{2}{*}{ Taxon } & \multirow{2}{*}{ Culture Accession } & \multicolumn{2}{|c|}{ GenBank Accession } \\
\hline & & LSU & SSU \\
\hline Acrospermum adeanum & M133 & EU940104 & EU940031 \\
\hline A. compressum & M151 & EU940084 & EU940012 \\
\hline A. gramineum & M152 & EU940085 & EU940013 \\
\hline Aliquandostipite khaoyaiensis & F89-1 & EF175647 & EF175625 \\
\hline A. khaoyaiensis & CBS 118232 & GU301796 & - \\
\hline Asterina cestricola & TH 591 & GU586215 & GU586209 \\
\hline A. fuchsiae & TH590 & GU586216 & GU586210 \\
\hline A. phenacis & TH589 & GU586217 & GU586211 \\
\hline A. weinmanniae & TH592 & GU586218 & GU586212 \\
\hline Botryobambusa fusicoccum & MFLUCC 11-0143 & JX646809 & JX646826 \\
\hline Botryosphaeria agaves & MFLUCC 11-0125 & JX646808 & JX646825 \\
\hline B. dothidea & CBS 115476 & DQ377852 & DQ677998 \\
\hline Chaetothyriothecium elegans & CPC 21375 & KF268420 & - \\
\hline Dendryphiopsis atra & AFTOL-ID 273 & DQ678046 & DQ677996 \\
\hline Guignardia bidwellii & AFTOL-ID 1618 & DQ678085 & DQ678034 \\
\hline G. citricarpa & CBS 102374 & DQ377877 & GU296151 \\
\hline Jahnula aquatica & R68-1 & EF175655 & EF175633 \\
\hline J. bipileata & F49-1 & EF175657 & EF175635 \\
\hline J. siamensiae & SS81.02 & EF175666 & EF175645 \\
\hline Kirschsteiniothelia aethiops & CBS 109.53 & AY016361 & AF346547 \\
\hline K. lignicola & MFLUCC 10-0036 & HQ441568 & HQ441569 \\
\hline Lasiodiplodia theobromae & CBS 164.96 & EU673253 & EU673196 \\
\hline Lichenothelia convexa & L1607 & KC015068 & KC015083 \\
\hline Manglicola guatemalensis & BCC20156 & KC015069 & KC015084 \\
\hline M. guatemalensis & BCC20157 & FJ743450 & FJ743444 \\
\hline Microthyrium microscopicum & CBS 115976 & GU301846 & GU296175 \\
\hline Muyocopron castanopsis & MFLUCC 10-0042 & - & JQ036225 \\
\hline M. castanopsis & MFLUCC 14-1108 & KU726965 & KU726968 \\
\hline M. dipterocarpi & MFLUCC 14-1103 & KU726966 & KU726969 \\
\hline M. garethjonesii* & MFLU 16-2664 & KY070274 & KY070275 \\
\hline M. lithocarpi & MFLUCC 10-0041 & JQ036230 & JQ036226 \\
\hline M. lithocarpi & MFLUCC 14-1106 & KU726967 & KU726970 \\
\hline Natipusilla bellaspora & PE91 1a & JX474864 & JX474868 \\
\hline$N$. decorospora & AF236 1a & HM196369 & HM196376 \\
\hline$N$. limonensis & AF286 1a & HM196370 & HM196377 \\
\hline N. naponensis & $\mathrm{AF} 2171 \mathrm{a}$ & HM196371 & HM196378 \\
\hline Neomicrothyrium siamense & IFRDCC 2194 & JQ036228 & JQ036223 \\
\hline Pleurotrema tiomanensis & NTOU3636 & КС692156 & КС692155 \\
\hline P. rhizophorae & JK 5456A & GU479799 & - \\
\hline P. rhizophorae & BCC15481 & - & KF160009 \\
\hline Tubeufia chiangmaiensis & MFLUCC 11-0514 & KF301538 & KF301543 \\
\hline T. miscanthi & MFLUCC 11-0375 & KF301533 & KF301541 \\
\hline T. paludosa & CBS 120503 & GU301877 & GU296203 \\
\hline
\end{tabular}

ABBREVIATIONS: AFTOL-ID: Assembling the Fungal Tree of Life: BCC: BIOTEC Culture Collection Laboratory: CBS: CBS-KNAW Fungal Biodiversity Centre, Utrecht, The Netherlands; JK: J. Kohlmeyer; KMUCC: Kunming Institute of Botany Culture; MFLUCC: Mae Fah Luang University Culture Collection, Chiang Rai, Thailand. 
Phylogenetic analyses

LSU and SSU sequence data we obtained from 45 taxa including our new taxon and the outgroup taxon (Table 1). Bootstrap support (BS) values of ML equal to or above $70 \%$ based on 1,000 replicates are shown in Fig. 1, from a best scoring RAxML analysis based on a combined aligned dataset of LSU and SSU sequence data. Bayesian posterior probabilities more than 0.90 are also shown on the nodes of the phylogenetic tree (Fig. 1). The phylogenetic tree obtained in this study shows similar results as in previous study by Mapook et al. (2016). The phylogenetic analyses shows our new taxon groups together with $M$. dipterocarpi, but is well-separated with strong support (70\% in ML, 0.90 in PP).

Table 2. Comparison of the Muyocopron spp. reported on Pandanaceae

\begin{tabular}{|c|c|c|c|c|}
\hline Taxa & Ascomata $(\mu \mathrm{m})$ & $\operatorname{Asci}(\mu \mathrm{m})$ & Ascospores $(\mu \mathrm{m})$ & Host/Distribution \\
\hline $\begin{array}{l}\text { M. pandani } \\
\text { Höhn. } 1920\end{array}$ & $200-500 \times 100-200$ & $26-30 \times 18-20$ & $12-15 \times 5-8$ & $\begin{array}{l}\text { Pandanus sp., } \\
\text { Indonesia }\end{array}$ \\
\hline $\begin{array}{l}\text { M. freycinetiae } \\
\text { (F. Stevens \& R.W. } \\
\text { Ryan) G. Arnaud } 1931\end{array}$ & $400-650$ & $34-50 \times 15-20$ & $13-18 \times 6-8$ & $\begin{array}{l}\text { Freycintia arnotti, } \\
\text { Hawaii }\end{array}$ \\
\hline
\end{tabular}

Tibpromma, Karun. \&

K.D. Hyde 2016

\section{Taxonomy}

Muyocopron garethjonesii Tibpromma, Karun. \& K.D. Hyde, sp. nov. Index Fungorum number: IF552529, Facesoffungi number: FoF02662

Etymology: Named in honour of Professor E.B. Gareth Jones who turns 80 years old in January 2017, in recognition of his immense contribution to mycology.

Holotype: MFLU 16-2664

Saprobic on dead leaves of Pandanus sp. Sexual morph: Colonies on natural substrate dry, black, circular, dull, undulate, umbonate, rough. Ascomata 110-130 $\mu \mathrm{m}$ high $\times 400-525 \mu \mathrm{m}$ diam. $(\overline{\mathrm{x}}=118 \times 478 \mu \mathrm{m}, \mathrm{n}=10)$, superficial, solitary or scattered, conspicuous at the host surface, appearing as circular, flattened, dark brown to black spots, carbonaceous, without a papilla, dull, with irregular margin, ostiole central. Peridium 32-70 $\mu \mathrm{m}$ wide, outer layer comprising dark brown to black, pseudoparenchymatous, occluded cells of textura angularis, inner layer comprising yellow-brown cells of textura angularis. Hamathecium comprising numerous, 1.5-2.4 $\mu \mathrm{m}$ wide, cylindrical to filiform, septate, unbranched pseudoparaphyses. Asci 60-120 × 19-35 $\mu \mathrm{m}(\overline{\mathrm{x}}=87 \times 28 \mu \mathrm{m}, \mathrm{n}=20), 4-8$-spored, bitunicate, broadly cylindrical to ovoid, with long pedicle. Ascospores 19-25 $\times 11-13 \mu \mathrm{m}(\overline{\mathrm{x}}=21 \times 12 \mu \mathrm{m}, \mathrm{n}=20)$, overlapping 1-2 seriate, hyaline to yellowish, 1-celled, ellipsoid to obovoid, granular, with one or two large oil guttules, lacking a mucilaginous sheath. Asexual morph: Undetermined. The mycelia produced pigments and hyphal coin structures (Fig. 3).

Culture characteristics: Colonies on MEA at room temperature $\left(20-25^{\circ} \mathrm{C}\right)$ reaching $4 \mathrm{~cm}$ in two weeks, circular with undulate, yellow-grey mycelium, velvety and flat on the media.

Material examined: CHINA, Yunnan Province, Xishuangbanna, Nabanhe Valley, on dead leaves of Pandanus sp. (Pandanaceae), 4 August 2016, S. Tibpromma \& S.C. Karunarathna NBH15 (MFLU 16-2664, holotype), ex-type living cultures, MFLUCC 16-1370, KMUCC 16-0150. 


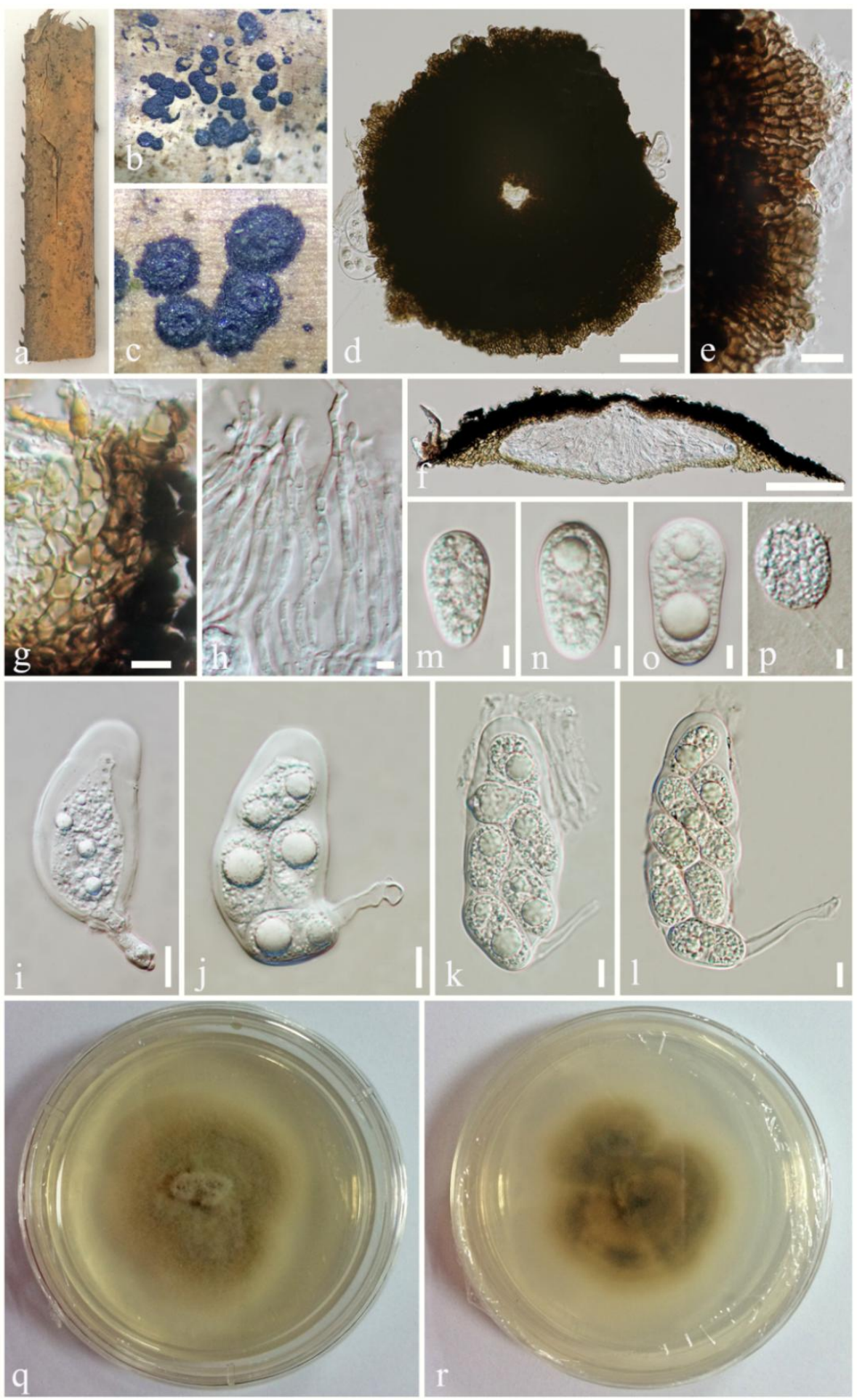

Fig. 2 Muyocopron garethjonesii (holotype). a-c Superficial ascomata on substrate. d, e Arrangement of cells in outer region of ascomata. $f$ Section of ascoma. g Peridium. $h$ Pseudoparaphyses. i-l Asci. m-o Ascospores. $\mathrm{p}$ Germinated ascospore. $\mathrm{q}, \mathrm{r}$ Colony on PDA after 7 days. Scale bars: $\mathrm{d}=100 \mu \mathrm{m}, \mathrm{e}=20 \mu \mathrm{m}, \mathrm{f}=100 \mu \mathrm{m}, \mathrm{g}=10 \mu \mathrm{m}, \mathrm{h}=5 \mu \mathrm{m}, \mathrm{i}-\mathrm{l}=10 \mu \mathrm{m}, \mathrm{m}-\mathrm{p}=$ $5 \mu \mathrm{m}$. 

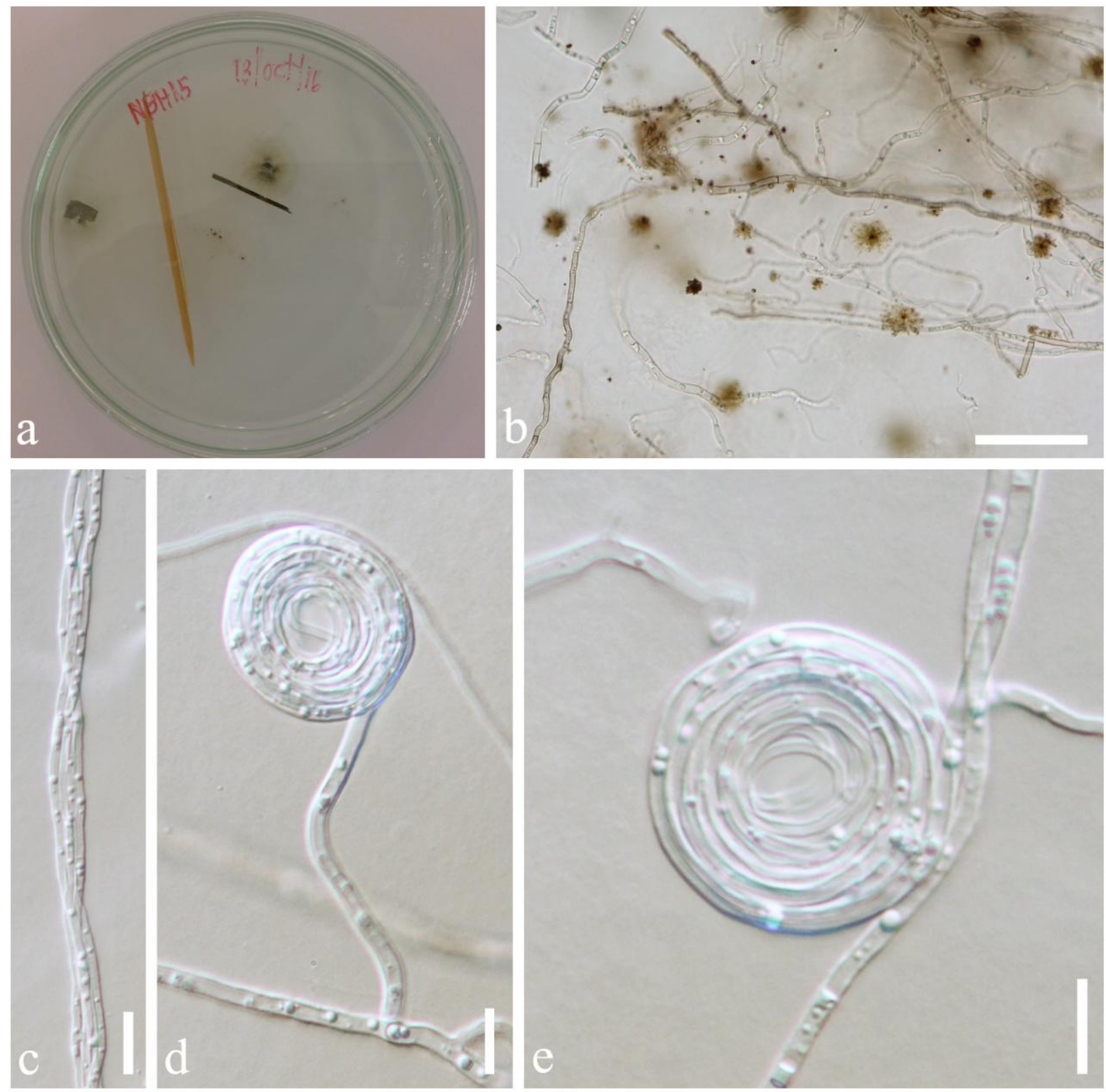

Fig. 3 Muyocopron garethjonesii (ex-type culture on WA media). a Growth of asexual morph on plant tissues. b Hyphae with produced pigments. c Hyphae. d, e Hyphal coil structures formed by mycelia. Scale bars: $\mathrm{b}=50 \mu \mathrm{m}, \mathrm{c}-\mathrm{e}=10 \mu \mathrm{m}$.

Notes: Muyocopron garethjonesii is introduced as a new species as it has distinct morphological features. These include a thick peridium, 4-8-spored, broadly cylindrical to ovoid, long pedicellate asci and hyaline to yellowish ascospores. We compare our new species with those known from Arecaceae and Pandanaceae (Taylor \& Hyde 2003). Muyocopron hongkongense, which was described from a palm, has saccate to clavate or obclavate asci, with granular ascospores (Taylor \& Hyde 2003). There are also obvious differences when compared to two other species of Muyocopron found on Pandanaceae (Table 2) with M. garethjonesii having larger ascospores. 


\section{Acknowledgements}

This project was supported by the National Natural Science Foundation of China (Nos. 31460009, 31500021). We would like to thank the Molecular Biology Experimental Center at Kunming Institute of Botany for help with the molecular phylogenetic work. Saowaluck Tibpromma thanks the Mushroom Research Foundation (MRF), Chiang Rai, Thailand for financial support. Kevin D. Hyde thanks Mae Fah Luang University grant "Biodiversity, phylogeny and role of fungal endophytes of Pandanaceae" (Grant number: 592010200112) and the Chinese Academy of Sciences, project number 2013T2S0030, for the award of Visiting Professorship for Senior International Scientists at Kunming Institute of Botany for supporting this study.

\section{References}

Ariyawansa HA, Hyde KD, Jayasiri SC, Buyck B et al. 2015 - Fungal diversity notes 111-252 taxonomic and phylogenetic contributions to fungal taxa. Fungal Diversity 75, 27-274

Cai L, Jeewon R, Hyde KD 2006 - Phylogenetic investigations of Sordariaceae based on multiple gene sequences and morphology. Mycological Research 110, 137-150 http://dx doi:10 1016/j mycres 200509014

Chomnunti P, Hongsanan S, Aguirre-Hudson B, Tian Q et al. 2014 - The sooty moulds. Fungal Diversity 66, 1-36

Eriksson OE 1981 - The families of bitunicate Ascomycetes. Opera Botanica 60, 1-209

Eriksson OE, Hawksworth DL 1993 - Notes on ascomycete systematic. Nos 1418-1529 Systema Ascomycetum 11, 163-194

Hyde KD, Jones EBG, Liu JK, Ariyawansa H et al. 2013 - Families of Dothideomycetes. Fungal Diversity 63, 1-313

Index Fungorum 2016 - Website http://www indexfungorum org/names/names asp

Jayasiri SC, Hyde KD, Ariyawansa HA, Bhat J et al. 2015 - The Faces of Fungi database: fungal names linked with morphology, phylogeny and human impacts. Fungal Diversity 74, 318

Katoh K, Standley DM 2016 - A simple method to control over-alignment in the MAFFT multiple sequence alignment program Bioinformatics, btw 108

Liu JK, Phookamsak R, Doilom M, Wiki S et al. 2012 - Towards a natural classification of Botryosphaeriales. Fungal Diversity 57, 149-210

Lumbsch HT, Huhndorf SM 2007 - Outline of Ascomycota - 2007. Myconet 13, 1-99

Lumbsch HT, Huhndorf SM 2010 - Outline of Ascomycota - 2009. Fieldiana Life and Earth Sciences 1, 1-60

Luttrell ES 1951 - Taxonomy of Pyrenomycetes. University of Missouri Studies 24(3), 1-120

Maharachchikumbura SSN, Hyde KD, Gareth EBG, McKenzie EHC et al. 2016 - Families of Sordariomycetes. Fungal Diversity 79, 1-317

Mapook A, Hyde KD, Dai DQ, Li J et al. 2016 - Muyocopronales, ord nov, (Dothideomycetes, Ascomycota) and a reappraisal of Muyocopron species from northern Thailand. Phytotaxa 265, 225-237

Miller MA, Pfeiffer W, Schwartz T 2010 - Creating the CIPRES Science Gateway for inference of large phylogenetic trees. In Gateway Computing Environments Workshop (GCE), 1-8 
Nylander JAA 2004 - MrModeltest 2.0 Program distributed by the author Evolutionary Biology Centre, Uppsala University

Pang KL, Hyde KD, Alias SA, Suetrong S, Jones EBG 2013 - Dyfrolomycetaceae, a new family in the Dothideomycetes, Ascomycota. Cryptogamie Mycologie 34, 223-232

Phipps CJ, Rember WC 2004 - Epiphyllous fungi the Miocene of Clarkia, Idaho reproductive structures Review of Palaeobotany and Palynology 129, 67-79

Phookamsak R, Norphanphoun C, Tanaka K, Dai DQ et al. 2015 - Towards a natural classification of Astrosphaeriella-like species, introducing Astrosphaeriellaceae and Pseudoastrosphaeriellaceae fam. nov. and Astrosphaeriellopsis, gen.nov. Fungal Diversity 74, 143-197.

Rambaut A, Drummond A 2008 - FigTree: Tree figure drawing tool, version 1.2.2. Institute of Evolutionary Biology, University of Edinburgh

Rannala B, Ziheng Y 1996 - "Probability distribution of molecular evolutionary trees: a new method of phylogenetic inference". Journal of Molecular Evolution 43, 304-311

Saccardo, P A (1883) Sylloge Fungorum Omnium hucusque cognitorum 2: 658-661

Spegazzini CL 1881 - Fungi argentini additis nonnullis brasiliensibus montevideensibusque Pugillus quartus (Continuacion). Anales de la Sociedad Científica Argentina 12, 97-117

Stamatakis A 2014 - "RAxML version 8: a tool for phylogenetic analysis and post-analysis of large phylogenies " Bioinformatics 30(9), 1312-1313

Taylor JE, Hyde KD 2003 - Microfungi of tropical and temperate palms. Fungal Diversity Research Series 12, 1-459

Tibpromma S, Boonmee S, Wijayawardene NN, Maharachchikumbura SSN et al. 2016a - The holomorph of Parasarcopodium (Stachybotryaceae), introducing P. pandanicola sp. nov, on Pandanus sp. Phytotaxa 266, 250-260

Tibpromma S, Bhat JD, Doilom M, Lumyong S et al. 2016b - Three new Hermatomyces species (Lophiotremataceae) on Pandanus odorifer from Southern Thailand. Phytotaxa 275, 127-139

Tibpromma S, Daranagama DA, Boonmee S, Promputtha I et al. 2016c - Anthostomelloides krabiensis gen et sp nov. (Xylariaceae) from Pandanus odorifer (Pandanaceae). Turkish Journal of Botany. DOI:10.3906/bot-1606-45

Vilgalys R, Hester M 1990 - Rapid genetic identification and mapping of enzymatically amplified ribosomal DNA from several Cryptococcus species. Journal of Bacteriology $172,4239-4246$

White T, Bruns T, Lee S, Taylor J 1990 - Amplification and direct sequencing of fungal ribosomal RNA genes for phylogenetics In: Innis M, Gelfand D, Shinsky J, White T (Eds ) PCR protocols: a guide to methods and applications. Academic Press, New York, 315-322

Whitton SR, McKenzie EHC, Hyde KD 2012 - Fungi associated with Pandanaceae. Fungal Diversity Research Series 21, 1-6

Zhaxybayeva O, Gogarten JP 2002 - Bootstrap, Bayesian probability and maximum likelihood mapping: exploring new tools for comparative genome analyses. BMC Genomics 3, 1 